\title{
Immunological and gene expression responses to a Salmonella infection in the chicken intestine
}

\author{
Saskia VAn HemerT*, Arjan J.W. Hoekman, Mari A. SMIts, \\ Johanna M.J. REBEL
}

\begin{abstract}
Animal sciences group of Wageningen UR, Infectious Diseases, PO Box 65, 8200 AB Lelystad, The Netherlands
\end{abstract}

(Received 27 February 2006; accepted 30 August 2006)

\begin{abstract}
Besides infection in humans, Salmonella enteritidis can also cause serious illness in young chickens. However, the genetic and immunological parameters important for the disease in chickens are not well characterized. In this study, processes in the chicken intestine in response to a Salmonella infection were investigated in two different chicken lines. One-day-old chickens were orally infected with Salmonella. T-cell subpopulations, phagocytic properties of intestinal mononuclear cells and RNA expression levels of the jejunum were investigated. The two chicken lines differed in the amount of cfu in the liver and growth retardation after the infection. Differences in phagocytic activity of intestinal mononuclear cells were found between control and Salmonella infected chickens. The number of $\mathrm{CD}^{+}{ }^{+} \mathrm{T}$-cells of the intestine decreased after the Salmonella infection in one chicken line, while the number of $\mathrm{CD}^{+} \mathrm{T}$-cells increased in both chicken lines, but the time post infection of this increase differed between the lines. In one chicken line the expression levels of the genes carboxypeptidase M and similar to ORF2 decreased after the Salmonella infection, which might be related to a decrease in the amount of macrophages. With the microarray, ten genes were found that were regulated in only one of the chicken lines, while we found six genes regulated in response to the infection in both chicken lines. So differences in genetic background of the chickens influence the intestinal host response of the Salmonella infection as observed by phagocytic activity, gene expression and changes in the number of T-cell subpopulations and macrophages.
\end{abstract}

immunology / microarray / Salmonella / T-cell

\section{INTRODUCTION}

Salmonella enterica is one of the most common causes of food poisoning in humans, mostly caused by poultry products infected by $S$. enterica serovars Typhimurium or Enteritidis [16]. In addition to the enteric disease in humans, Salmonella serovars Typhimurium and En-

* Corresponding author:

Saskia.vanhemert@wur.nl teritidis are also capable of causing severe systemic disease in newly hatched chicks and in birds under extreme stress conditions [19]. In young chickens, infection with Salmonella leads to diarrhea and intestinal lesions and to an influx of heterophils into the gut accompanied by inflammation and damage to villi [3].

An infection with Salmonella usually starts by ingestion, followed by colonization in the intestine. After colonization, Salmonella is able to penetrate the 
mucosal epithelium which results in a systemic infection, with colonization of the spleen and liver [9]. The immunological responses in the chicken intestine to a Salmonella infection are not fully understood. In general, the innate immune system plays an important role in the early response to Salmonella. Upon oral challenge with Salmonella the area occupied by the macrophages in the caecal wall was increased in neonatal chickens [24]. Macrophage-derived cytokines and immune mediators can initiate local and systemic inflammatory responses. This local inflammation likely explains the strong influx and continued presence of macrophages and T-cells after a Salmonella infection [24]. It was also shown that after infection with Salmonella the number of $\mathrm{CD}^{+} \mathrm{TCR} \gamma \delta^{+} \mathrm{T}$-cells in the chicken intestine increased [6]. CD4 ${ }^{+}$ or $\mathrm{CD}^{+} \mathrm{T}$-cell responses are not required for the early host response [14], but $\mathrm{CD}^{+}{ }^{+} \mathrm{T}$-cell responses, particularly $\mathrm{Th} 1$ responses, play an important role in the clearance of Salmonella from the gastrointestinal tract [5, 10,27].

Earlier gene expression studies suggested that innate immunity, inflammation and T-cell responses are important processes in the chicken intestine in response to a Salmonella infection [23]. However, these findings were only based on gene expression data of one chicken experiment. To further evaluate immune responses in the one-day-old chicken intestine after a Salmonella infection, differences in T-cell populations were investigated as were phagocytic properties of intestinal mononuclear cells and RNA expression.

\section{MATERIALS AND METHODS}

\subsection{Chickens}

Two meat type chicken lines, a fast growing line $\mathrm{F}$ and a slow growing line $\mathrm{S}$ were used in the present study (Nutreco ${ }^{\circledR}$, Boxmeer, The Netherlands). Line $\mathrm{S}$ is a commercial dam line from white plymouth rock origin. Line $\mathrm{F}$ is an experimental line selected for egg production, liveability and slow growth to be used in the future for processing of broilers of 80 days and older. As indicated in the results section, these lines differed in growth retardation and amount of colony forming units in the liver after Salmonella infection. One-day old chickens of each line ( $\mathrm{F}$ and $\mathrm{S}$ ) were randomly divided into 2 groups, 40 chickens each. After hatching, birds were checked to be free of Salmonella.

\subsection{Experimental infection}

Salmonella enterica serovar Enteritidis phage type 4 (nalidixic acid resistant) was grown in buffered peptone water (BPW) overnight while shaking. In each chicken line, one group of 1-day old chickens was orally inoculated with $0.2 \mathrm{~mL}$ of the bacterial suspension containing $10^{5} \mathrm{cfu} S$. enterica serovar Enteritidis. The control groups were inoculated with $0.2 \mathrm{~mL}$ saline. Ten chickens of each group were randomly chosen, weighed and sacrificed at days 1 , 5 and 7 post infection (pi). Pieces of the jejunum were snap frozen in liquid nitrogen and stored at $-70{ }^{\circ} \mathrm{C}$ for immunohistochemistry and RNA isolation. The remaining part of the jejunum was stored in buffered saline at $4{ }^{\circ} \mathrm{C}$ until isolation of intestinal mononuclear cells. The liver was removed and weighed and kept at $4{ }^{\circ} \mathrm{C}$ until bacteriological examination. At day 9 the chickens were weighed only and at day 12 the chickens were weighed and bacteriological examinations were performed, but no mononuclear cells or RNA was isolated. The study was approved by the institutional Animal Experiment Commission in accordance with Dutch regulations on animal experimentation. 


\subsection{Bacteriological examination}

For detection of $S$. serovar Enteritidis a cloacal swab was taken and after overnight enrichment it was spread on brilliant green agar $+100 \mathrm{ppm}$ nalidixic acid for Salmonella determination $\left(37^{\circ} \mathrm{C}\right.$, 18-24 h). One gram of liver of each bird was homogenized in $9 \mathrm{~mL}$ BPW, serial diluted in BPW, and plated onto brilliant green agar with nalidixic acid for quantitative $S$. serovar Enteritidis determination $\left(37^{\circ} \mathrm{C}, 18-24 \mathrm{~h}\right)$ by counting the colony forming units. To identify significant differences between the two chicken lines, a student- $t$ test was performed on the logtransformed data.

\subsection{Intestinal mononuclear cell isolation}

The jejunum was opened longitudinally, washed with phosphate buffered saline (PBS) and cut into pieces of $1 \mathrm{~cm}$. These pieces were incubated at $37^{\circ} \mathrm{C}$ for $45 \mathrm{~min}$ in Medium I (PBS containing $1 \mathrm{mM}$ EDTA and $5 \mathrm{mM}$ DTT). The suspension contained the intraepithelial cells (fraction 1) and was kept at $4{ }^{\circ} \mathrm{C}$ until use. The remaining pieces of intestine were further incubated at $37{ }^{\circ} \mathrm{C}$ for $90 \mathrm{~min}$ in Medium II $($ RPMI $+5 \%$ fetal calf serum (FCS) + 400 FALGPA units Collagenase per liter (Sigma, St. Louis, MO, USA) + $60000 \mathrm{Ku}-$ nitz units DNase I per liter (Sigma)) while shaking (fraction 2, lamina propria cells). The two fractions were mixed and after centrifugation for $10 \mathrm{~min}$ at $460 \times g$ the pellet was resuspended in $10 \mathrm{~mL}$ Medium III (RPMI $+1 \%$ FCS +60000 Kunitz units DNase I per liter). The suspension was purified on a $25 \%$ percoll (Sigma) gradient centrifuging for $15 \mathrm{~min}$ at $2000 \mathrm{rpm}$. The pellet was washed twice with PBS and the cells were coloured with $0.1 \%$ trypan blue and viable (unstained) cells were counted. The cells were resuspended in PBS at a concentration of $1 \times 10^{6}$ cells per $\mathrm{mL}$.

\subsection{Phagocyte activity of intestinal mononuclear cells}

The intestinal mononuclear cell isolates were tested for their phagocytic activity by intake of live Salmonella enteritidis phage type 4 as described by Kramer et al. [12]. Briefly, the gut mononuclear cell suspension was diluted to $1 \times 10^{7}$ cells $/ \mathrm{mL}$ in RPMI. One milliliter of Salmonella enteritidis (overnight culture 1:100 diluted and grown for approximately $3 \mathrm{~h}$, about $1 \times 10^{8} \mathrm{cfu}$ ) was added and the mixture was incubated for $45 \mathrm{~min}$ at $37^{\circ} \mathrm{C}$. Subsequently, $200 \mu \mathrm{g}$ gentamycin was added to kill non-internalized bacteria and incubated for $45 \mathrm{~min}$ at room temperature. After washing in PBS the cells were lysed by adding $1 \mathrm{~mL} 0.2 \%$ saponine in PBS and incubating $5 \mathrm{~min}$ to release the bacteria internalized by the phagocytic intestinal mononuclear lymphocytes. The number of $S$. enteritidis internalized by the cells was counted on $\mathrm{BGA}^{-\mathrm{NaI}^{+}}$plates. A higher value indicated a higher phagocytic activity of the mononuclear cells.

\subsection{Flow cytometry}

The total leukocyte subpopulation of the intestinal mononuclear cell isolates was estimated by flow cytometry. For the flow cytometric analysis the concentration of the isolated cells was brought to $20 \times$ $10^{6}$ cells $/ \mathrm{mL}$, and $50 \mu \mathrm{L}$ was transferred into a 96 well plate on ice. The cells were washed with PBS supplemented with $1 \%$ FCS. A normal mouse serum (1\%) was applied to block non-specific binding sites, followed by adding the monoclonal antibody CD45-PE (Southern Biotech, Birmingham, Alabama, USA). After $15 \mathrm{~min}$ incubation at $4{ }^{\circ} \mathrm{C}$, the cells were washed twice with PBS/FCS and re-suspended in $200 \mu \mathrm{L}$ ice-cold PBS/FCS. A total of $10^{4}$ cells per sample were analyzed by flow cytometry (FACS Calibur ${ }^{\mathrm{TM}}$, Beckton 
Dickinson, Leiden, The Netherlands). The data were analyzed using a flow cytometry computer program.

\subsection{Immunohistochemistry}

Frozen jejunum sections collected at days 1,5 and 7 pi were stained for $\mathrm{CD} 4^{+}$ T-cells, $\mathrm{CD}^{+}$T-cells and macrophages. Immunohistological staining by an indirect immunoperoxidase method was performed on frozen tissue sections $(10 \mu \mathrm{m}$ thick). The sections were loaded on glass slides, air-dried, and fixed in acetone for $10 \mathrm{~min}$. After being dried, the slides were immersed in PBS with $0.1 \%$ BSA and were subsequently incubated for $1 \mathrm{~h}$ with monoclonal antibodies against macrophages (1:500 CVIChNL68.1 [11]), CD4 ${ }^{+}$T cells (1:200 CT-4 Southern Biotech), or CD8 ${ }^{+}$ T cells (1:200 CT-8 Southern Biotech) followed by peroxidase-conjugated rabbit anti-mouse Ig (1:80 Dakopatts, Denmark). Peroxidase activity was detected by $0.05 \% 3,3$-diaminobenzidine (DAB) in $0.1 \mathrm{M}$ Tris- $\mathrm{HCl}$ solution ( $\mathrm{pH} 7.5$ ) containing $0.03 \% \mathrm{H}_{2} \mathrm{O}_{2}$. The sections were further colored with $1 \% \mathrm{CoCl}_{2}$ for $5 \mathrm{~min}$. After washing, the nuclei were counter-stained with hematoxylin. The sections were dehydrated and mounted in distyrene-tricresyl phosphate-xylene (DPX). The images were acquired and analyzed with Image-Pro Plus (version 5.1, media cybernetics).

\subsection{RNA isolation}

Pieces of the jejunum were crushed under liquid nitrogen. Fifty to hundred mg tissues of the different chicks were used to isolate total RNA using TRIzol reagent (Invitrogen, Breda, The Netherlands), according to instructions of the manufacturer with an additional step. The homogenized tissue samples were resuspended in $1 \mathrm{~mL}$ of TRIzol Reagent using a syringe and
21 gauge needle and passing the lysate through 10 times. After homogenization, insoluble material was removed from the homogenate by centrifugation at $12000 \times g$ for $10 \mathrm{~min}$ at $4{ }^{\circ} \mathrm{C}$. For the array hybridization, pools of RNA were made in which equal amounts of RNA from ten different chickens of the same line, condition and timepoint were present.

\subsection{Hybridizing of the microarray}

The microarrays were constructed as described earlier [21]. The microarrays contained 3072 cDNA from a subtracted intestinal library and 1152 cDNA from a concanavalin A stimulated spleen library. All cDNA were spotted in triplicate on each microarray. Before hybridization, the microarray was pre-hybridized in $5 \% \mathrm{SSC}, 0.1 \% \mathrm{SDS}$ and $1 \% \mathrm{BSA}$ at $42{ }^{\circ} \mathrm{C}$ for $30 \mathrm{~min}$. To label the RNA, the MICROMAX TSA labeling and detection kit (PerkinElmer, Wellesley, MA, USA) was used. The TSA probe labeling and array hybridization were performed as described in the instruction manual with minor modifications. Biotin- and fluorescein-labeled cDNA were generated from $5 \mu \mathrm{g}$ of total RNA from the chicken jejunum pools per reaction. The cDNA synthesis time was increased to $3 \mathrm{~h}$ at $42{ }^{\circ} \mathrm{C}$. The generated cDNA was transferred to a microcon YM-100 centrifugal filter cartidge (Millipore, Billerica, MA, USA) and washed twice with $10 \mathrm{mM}$ Tris$\mathrm{HCl}, \mathrm{pH}$ 7.5. The cDNA was resolved in $60 \mu \mathrm{L}$ hybridization buffer from the kit and heated to $95^{\circ} \mathrm{C}$ for $2 \mathrm{~min}$. Hybridization of the array was done during 16-20 h at $65{ }^{\circ} \mathrm{C}$. Post-hybridization washes were performed according to the manufacturer's recommendations. Hybridizations were performed in duplicate with the fluorophores reversed. After signal amplification, the microarrays were dried and scanned for $\mathrm{Cy} 5$ and $\mathrm{Cy} 3$ fluorescence in 
a Packard Bioscience BioChip Technologies apparatus. The image was processed with Genepix pro 5.0 (Genomic Solutions, Ann Arbor, MI, USA) and the spots were located and integrated with the spotting file of the robot used for spotting. Reports were created of total spot information and spot intensity ratio for subsequent data analyses.

\subsection{Analysis of the microarray data}

Each spot was corrected for local background and the data for each slide were normalized so that the mean of the ratio of all spots was equal to one with the GenePix Pro 5.0 program. A total of 8 microarrays were used in this experiment. The following four comparisons were made using pools of RNA from ten different chickens:1- line F (fast growing) control vs. line S (slow growing) control; 2-line F Salmonella vs. line S Salmonella; 3-line F control vs. line F Salmonella; and 4-line $\mathrm{S}$ control vs. line S Salmonella. For each comparison, six values were obtained per gene, three for one slide and three for the dye-swap. Genes with two or more missing values were removed from further analysis. Missing values were possibly due to a bad signal to noise ratio. A gene was considered to be differentially expressed when the mean value of the ratio $\log 2$ (Cy5/Cy3) was $>1.58$ or $<-1.58$ and the cDNA was identified with a one class significance analysis of microarrays (based on SAM [20]) with a False discovery rate $<2 \%$. Because the ratio was expressed in a $\log 2$ scale, a ratio of $>1.58$ or $<-1.58$ corresponded to a more than threefold up- or downregulation respectively, which is the expression difference limit indicated by the manufacturer of the MICROMAX TSA labeling and detection kit.

\subsection{Quantitative real time PCR}

A quantitative PCR was performed as described previously [22]. Briefly, 200 ng of total RNA from the jejunum was reverse transcribed with random hexamers. Generated cDNA was stored at $-20{ }^{\circ} \mathrm{C}$ until use. PCR amplification and analysis was done with the described primers and conditions (Tab. I). 28S was used as a control to correct for the input of cDNA. Each reaction mixture consisted of $1 \mu \mathrm{L}$ cDNA (1:10 diluted), $1 \mu \mathrm{L}$ of each primer $(10 \mu \mathrm{M}$ solution), $2 \mu \mathrm{L}$ LightCycler FastStart DNA Master SYBR Green mix, $3 \mathrm{mM} \mathrm{MgCl}_{2}$ in a total volume of $20 \mu \mathrm{L}$. All templates were amplified with a preincubation for $10 \mathrm{~min}$ at $95^{\circ} \mathrm{C}$ followed by amplification for 40 cycles: $\left(5 \mathrm{~s}\right.$ at $95^{\circ} \mathrm{C}, 10 \mathrm{~s}$ at annealing temperature, $15 \mathrm{~s}$ at $72{ }^{\circ} \mathrm{C}$ ).

In each run, four standards of the gene of interest were included with appropriate dilutions of the DNA, to determine the cDNA concentration in the samples. All RT-PCR amplified a single product as determined by melting curve analysis. To see if the groups differed significantly, a student- $t$ test was performed on the log transformed concentrations corrected for the amount of $28 \mathrm{~S}$ and $p<0.05$ was considered as significant.

\section{RESULTS}

\subsection{Bacteriological examination and body weight}

In all the animals inoculated with Salmonella enterica serovar Enteritidis, the Salmonella was detected in the feces at all time points analyzed by bacterial platings. In contrast, S. enterica serovar Enteritidis was detected in none of the control animals. The number of $S$. enterica serovar Enteritidis found in the liver of chickens from the fast growing $(\mathrm{F})$ and slow growing $(\mathrm{S})$ lines is presented in Figure 1. At days 1 and 5 pi the chickens from line $S$ had more cfu Salmonella in the liver compared to line $\mathrm{F}(p<0.05)$.

Since Line $F$ was the fast growing chicken line, from day 5 onwards the 
Table I. Primers and RT-PCR conditions for different genes.

\begin{tabular}{lllc}
\hline Gene & Forward primer & Reverse primer & $\begin{array}{c}\text { Annealing } \\
\text { temperature }\end{array}$ \\
\hline XM_416896 (lysozyme G) & CGGCTTCAGAGAAGATTG & GTACCGTTTGTCAACCTGC & $62{ }^{\circ} \mathrm{C}$ \\
XM_416085 (carboxypeptidase M) & ATTCTGGAGAGACAACAAAGTTGCT & TTTGGCTTCCACGATTGCA & $58{ }^{\circ} \mathrm{C}$ \\
XM_425603(ORF2) & GTCAGCCTCTTCTCTCGTGTGA & AGTGCCTGACCACCCTTTCA & $58{ }^{\circ} \mathrm{C}$ \\
BX930518 (clone ChEST640b17) & GAATCAAGCAACTTCCGTACCAT & AGGTTCCAAGAGCCTGAAAGTTC & $59^{\circ} \mathrm{C}$ \\
XM_420282 (DNA segment, Chr 10) & TCTTCCCAGGCTGTGAG & GGTCACCAGCTTGTTCTTC & $64{ }^{\circ} \mathrm{C}$ \\
NM_205513(calbindin) & CATGGATGGGAAGGAGC & GCTGCTGGCACCTAAAG & $56^{\circ} \mathrm{C}$ \\
DQ_018756(28S) & TCAACTTTCCCTTACGGTAC & CAAGTCCTTCTGATCGAG & $56{ }^{\circ} \mathrm{C}$ \\
\hline
\end{tabular}

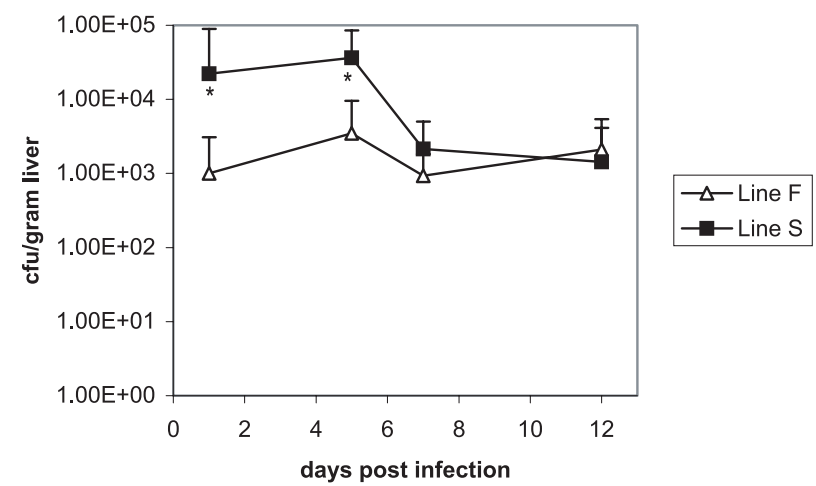

Figure 1. Number of cfu of $S$. enteritidis in the liver of chickens from the two chicken lines. Error bars indicate the SEM $(n=10)$. *Infected chickens from line F have significant less cfu Salmonella in the liver than chickens from line $\mathrm{S}(p<0.05)$.

healthy chickens from this line were heavier than the healthy chickens from line $\mathrm{S}$ $(p<0.001)$. The chickens from line $\mathrm{S}$ had a weight gain depression due to the Salmonella infection $(p<0.01)$ while the chickens from line $\mathrm{F}$ had no significant weight gain depression after the Salmonella infection (Fig. 2).

\subsection{Phagocytic activity and flow cytometric analysis of intestinal cells}

The phagocytic activity of the isolated intestinal mononuclear cells was measured with the phagocyte assay and the results are shown in Table II. However, at least $1 \times 10^{7}$ mononuclear cells per chicken were necessary for this assay and not enough cells were isolated from all jejunums. Therefore, for this assay 3 to 10 animals per group were used. The isolated intestinal mononuclear cells were stained with trypan blue to check the viability of the cells and were analyzed with FACS for the percentage of $\mathrm{CD} 45^{+}$cells. The gated mononuclear $\mathrm{CD} 45^{+}$cells in the jejunum increased with the age of the chickens (Fig. 3). At day 1 pi the Salmonella infected chickens from line $F$ had a significant lower percentage $\mathrm{CD} 45^{+}$cells compared to their healthy counterparts $(p<$ $0.01)$.

For the phagocytic activity, only effects within each day can be compared, due to the differences in number of bacteria 

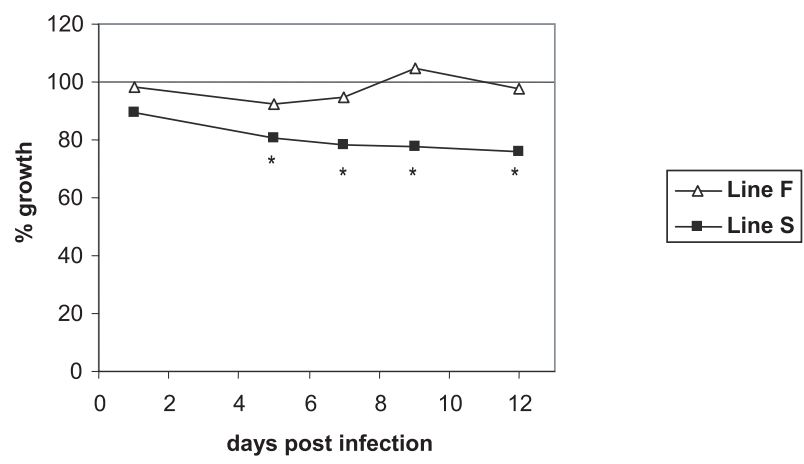

Figure 2. Percentage growth of chickens infected with $10^{5} \mathrm{~S}$. enteritidis compared to healthy counterparts. *Infected chickens are significantly lighter than age-matched healthy counterparts from the same line $(p<0.05)$.

Table II. Phagocytic activity of mononuclear gut cells of chickens ${ }^{\mathrm{a}}$.

\begin{tabular}{lcccccc}
\hline \multirow{2}{*}{ Line } & \multicolumn{2}{c}{ Day 1 } & \multicolumn{2}{c}{ Day 5 } & \multicolumn{2}{c}{ Day 7 } \\
\cline { 2 - 7 } & control & infected & control & infected & control & infected \\
\hline F & $9( \pm 5)^{\mathrm{b}}$ & $64( \pm 9)$ & $5( \pm 1)$ & $5( \pm 4)$ & $357( \pm 26)$ & $364( \pm 32)$ \\
$\mathrm{S}$ & $33( \pm 10)$ & $48( \pm 8)$ & $7( \pm 1)^{\mathrm{b}}$ & $16( \pm 4)$ & $378( \pm 33)$ & $396( \pm 33)$ \\
\hline
\end{tabular}

a Total number $\times 10^{3}$ of internalized bacteria by all cells \pm SEM.

${ }^{\mathrm{b}}$ Significant difference between control and Salmonella infected chickens $(p<0.05)$.

between the overnight Salmonella cultures for the different days pi. At day 1 pi the cells isolated from the Salmonella infected chickens from line $\mathrm{F}$ had almost 7 times more bacteria internalized compared with the cells from the control chickens $(p<$ $0.01)$. In contrast, in line $S$ no differences between the cells of the control chickens and the Salmonella infected chickens were found at day 1 pi (Tab. II). However, at day 5 pi the cells from the Salmonella infected chickens from line $\mathrm{S}$ internalized two times more bacteria than the cells from the control chickens from the same line $(p<0.05)$. At day 5 pi in line $\mathrm{F}$, no differences in the amount of internalized bacteria between the control and the Salmonella infected chickens were found (Tab. II). At day 7 pi no differences in phagocytic activity were found between cells from the Salmonella infected and the control chickens.

\subsection{Immunohistochemistry}

Frozen jejunum sections from all animals were quantified for CD4 positive T-cells, CD8 positive T-cells and macrophages with immunohistochemistry and we found small but significant differences between the groups (Tab. III). The number of $\mathrm{CD}^{+}$T-cells per $\mathrm{mm}^{2}$ was at day 1 and day 5 pi lower in the Salmonella infected chickens from line $\mathrm{F}$ compared to the healthy age-matched controls from the same line. There were no clear differences in the location of the $\mathrm{CD} 4^{+} \mathrm{T}$-cells, since most cells were located in the lamina propria. For line $\mathrm{S}$ no differences in the 


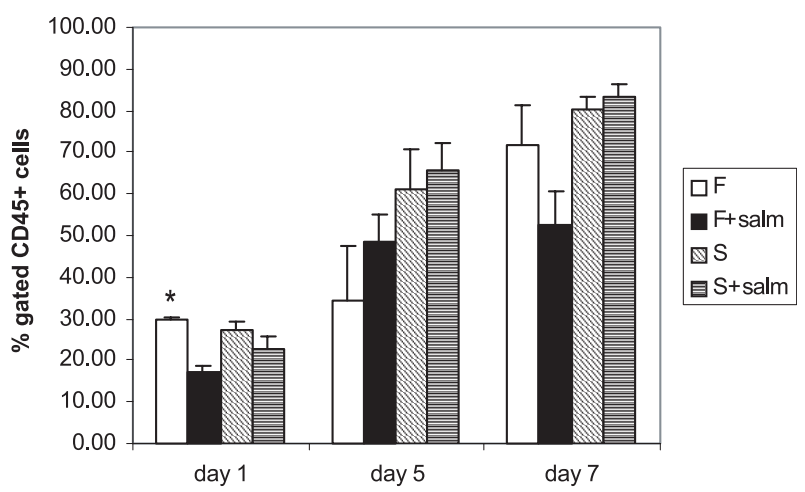

Figure 3. Amount of $\mathrm{CD} 45^{+}$cells in the isolated intestinal mononuclear cells as a percentage of the gated intestinal mononuclear cells. $\mathrm{F}=$ fast growing chicken line, $\mathrm{S}=$ slow growing chicken line, + salm $=$ infected with Salmonella enteritidis. Standard bars indicate the SEM $(n=3-10)$.

* Significant difference between cells from control and infected chickens $(p<0.01)$.

Table III. Mean number $( \pm \mathrm{SEM})$ of $\mathrm{CD}^{+}, \mathrm{CD}^{+}$and macrophages per $\mathrm{mm}^{2}$.

\begin{tabular}{|c|c|c|c|c|c|c|}
\hline \multirow{2}{*}{ Line } & \multicolumn{2}{|c|}{ Day 1} & \multicolumn{2}{|c|}{ Day 5} & \multicolumn{2}{|c|}{ Day 7} \\
\hline & Control & Infected & Control & Infected & Control & Infected \\
\hline \multicolumn{7}{|c|}{$\mathrm{CD}^{+}{ }^{+}$T-cells } \\
\hline $\mathrm{F}$ & $14( \pm 2)^{\mathrm{a}}$ & $8( \pm 1)$ & $45( \pm 3)^{\mathrm{a}}$ & $33( \pm 3)$ & $100( \pm 4)$ & $113( \pm 7)$ \\
\hline S & $12( \pm 2)$ & $16( \pm 2)$ & $68( \pm 5)$ & $54( \pm 8)$ & $74( \pm 7)$ & $91( \pm 5)$ \\
\hline \multicolumn{7}{|c|}{$\mathrm{CD} 8^{+} \mathrm{T}$-cells } \\
\hline $\mathrm{F}$ & $38( \pm 4)$ & $57( \pm 8)$ & $329( \pm 27)$ & $300( \pm 29)$ & $211( \pm 21)^{\mathrm{a}}$ & $335( \pm 24)$ \\
\hline S & $32( \pm 6)$ & $26( \pm 3)$ & $168( \pm 11)^{\mathrm{a}}$ & $237( \pm 24)$ & $193( \pm 15)^{\mathrm{a}}$ & $254( \pm 19)$ \\
\hline \multicolumn{7}{|c|}{ Macrophages } \\
\hline $\mathrm{F}$ & $226( \pm 14)$ & $241( \pm 17)$ & $353( \pm 16)$ & $382( \pm 19)$ & $451( \pm 44)$ & $485( \pm 36)$ \\
\hline S & $213( \pm 14)^{\mathrm{a}}$ & $124( \pm 8)$ & $391( \pm 30)$ & $395( \pm 25)$ & $469( \pm 25)$ & $457( \pm 16)$ \\
\hline
\end{tabular}

${ }^{a}$ Significant difference between control and Salmonella infected chickens $(p<0.05)$.

amount or location of $\mathrm{CD} 4^{+} \mathrm{T}$-cells was found between the control and the infected chickens. The number of $\mathrm{CD}^{+} \mathrm{T}$-cells was increased at day 7 pi in the infected chickens from line S compared to their controls and at days 5 and 7 pi for the infected chickens from line $\mathrm{F}$.

At day 1 pi, the number of macrophages in the Salmonella infected chickens from line $\mathrm{S}$ was lower than the healthy chick- ens from line $\mathrm{S}$ or the Salmonella infected chickens from line F. At later timepoints, no significant differences between the amounts of macrophages were found.

\subsection{Gene expression in the chicken intestine}

RNA was isolated from the chicken jejunum day 1 pi to investigate gene 
Table IV. Fold changes in mRNA compared with age-matched mock-infected controls $24 \mathrm{~h}$ after the Salmonella infection.

\begin{tabular}{|c|c|c|c|}
\hline \multirow{2}{*}{ Accession No. } & \multirow{2}{*}{ Gene name } & \multicolumn{2}{|c|}{ Foldchange (infected/ control) } \\
\hline & & Line $\mathrm{F}$ & Line $S$ \\
\hline \multicolumn{4}{|c|}{ Genes regulated in line $\mathrm{S}$ after Salmonella infection } \\
\hline XM_416896.1 & PREDICTED: Gallus gallus similar to lysozyme G & 1.0 & 6.9 \\
\hline CR522945 & finished cDNA, clone ChEST753p12 & 1.3 & 4.2 \\
\hline XM_418587 & $\begin{array}{l}\text { PREDICTED: Gallus gallus similar to CG3524-PA } \\
\text { (LOC420485) }\end{array}$ & 1.5 & 3.1 \\
\hline DN828701 & expressed sequence tag (Chr:2 80621800 -80622343) & -1.7 & -27.4 \\
\hline XM_416085.1 & $\begin{array}{l}\text { PREDICTED: Gallus gallus similar to Carboxypep- } \\
\text { tidase M precursor (LOC417843), mRNA }\end{array}$ & -2.0 & -7.2 \\
\hline XM_425603.1 & $\begin{array}{l}\text { PREDICTED: Gallus gallus similar to ORF2 } \\
\text { (LOC428036), mRNA }\end{array}$ & -2.3 & -6.1 \\
\hline XM_423002.1 & $\begin{array}{l}\text { similar to Rho GTPase-activating protein; brain- } \\
\text { specific Rho GTP-ase-activating protein }\end{array}$ & -1.8 & -4.7 \\
\hline BX930518.1 & Gallus gallus finished cDNA, clone ChEST640b17 & -1.0 & -3.5 \\
\hline BU457068.1 & cDNA clone ChEST200c16 & -1.2 & -3.3 \\
\hline \multicolumn{4}{|c|}{ Genes regulated in line $\mathbf{F}$ after Salmonella infection } \\
\hline NM_204192.1 & Gallus gallus fatty acid binding protein 1 , liver & -4.0 & -1.1 \\
\hline \multicolumn{4}{|c|}{ Genes regulated after a Salmonella infection in both chicken lines } \\
\hline XM_420282.1 & $\begin{array}{l}\text { PREDICTED: Gallus gallus similar to DNA seg- } \\
\text { ment, Chr 10, Johns Hopkins University } 81 \text { expressed }\end{array}$ & 4.8 & 19.1 \\
\hline NM_001006208 & $\begin{array}{l}\text { Gallus gallus ras homolog gene family, member T1 } \\
\text { (RHOT1) }\end{array}$ & 7.9 & 15.0 \\
\hline NM_205125.1 & Gallus gallus dickkopf homolog 3 & 4.7 & 14.2 \\
\hline XM_418586 & $\begin{array}{l}\text { PREDICTED: Gallus gallus similar to Fatty acid } \\
\text { synthase }\end{array}$ & 3.7 & 6.0 \\
\hline NM_204933.1 & Gallus gallus cytidine deaminase (CDD) & 2.9 & 3.6 \\
\hline NM_205513.1 & Gallus gallus calbindin 1, $28 \mathrm{kDa}$ & -3.2 & -3.8 \\
\hline
\end{tabular}

expression responses to Salmonella. By comparing the gene expression responses of both chicken lines, we found more differences than similarities 1 day pi. After the Salmonella infection three genes were more than threefold upregulated and six genes were more than threefold downregulated in line S, but not in line F (Tab. IV). In line $\mathrm{F}$, liver fatty acid binding protein was downregulated after the infection, whereas no significant regulation was observed in line $\mathrm{S}$.

In addition to the genes regulated after the Salmonella infection in one of the chicken lines, some genes were regulated in both chicken lines. Similar to DNA segment, Chr 10, ras homolog gene family member T1, dickkopf homolog 3, similar to fatty acid synthase and cytidine deaminase were upregulated, whereas calbindin 
Table V. Expression differences found with the microarray compared with the q-PCR.

\begin{tabular}{|c|c|c|c|c|}
\hline \multirow{3}{*}{ Gene } & \multicolumn{2}{|c|}{ Line F } & \multicolumn{2}{|c|}{ Line $\mathrm{S}$} \\
\hline & \multicolumn{2}{|c|}{ Ratio Salmonella/control $^{\mathrm{a}}$} & \multicolumn{2}{|c|}{ Ratio Salmonella/control $^{\mathrm{a}}$} \\
\hline & Microarray & q-PCR & Microarray & $\mathrm{q}-\mathrm{PCR}$ \\
\hline XM_416896 (lysozyme G) & 1.0 & -1.0 & 6.9 & $14.0^{\mathrm{b}}$ \\
\hline XM_416085 (carboxipeptidase M) & -2.0 & -1.1 & -7.2 & $-3.2^{b}$ \\
\hline XM_425603 (ORF2) & -2.3 & -1.3 & -6.1 & $-2.4^{\mathrm{b}}$ \\
\hline BX930518 (clone ChEST640b17) & -1.0 & -1.1 & -3.5 & $-3.0^{\mathrm{b}}$ \\
\hline XM_420282 (DNA segment, Chr 10) & 4.8 & $3.9^{\mathrm{b}}$ & 19.1 & $14.1^{\mathrm{b}}$ \\
\hline NM_205513 (calbindin) & -3.2 & $-2.6^{\mathrm{b}}$ & -3.8 & $-2.8^{\mathrm{b}}$ \\
\hline
\end{tabular}

${ }^{a}$ When the ratio (Salmonella/control) is smaller than 1, the ratio -(control/Salmonella) is given.

b The expression levels of the control and Salmonella infected group from the same chicken line differ significantly (student $t$-test, $p<0.05$ ).

was downregulated more than threefold in both chicken lines (Tab. IV).

For lysozyme G, carboxypeptidase M, similar to ORF2, cDNA clone ChEST640b17, similar to DNA segment, Chr 10 and calbindin a quantitative PCR was performed on the individual samples. For all these genes, the up- or downregulation we found with the microarray was confirmed with the RT-PCR. Furthermore, when more than threefold expression differences were detected with the microarray, which was our threshold to call a gene up- or downregulated, the expression levels differed significantly $(p<0.05)$ between the control and the Salmonella infected chickens from the same line (Tab. V).

\section{DISCUSSION}

Salmonella bacteria that reach the intestinal tract can cross the intestinal epithelium after attachment to the mucosa. From there, they can reach the lamina propria, where they replicate or penetrate into deeper tissues. After reaching the blood stream, they infect internal organs, such as the liver and spleen. In our experiment, colonization of the liver started already 1 day post inoculation, with 40 and $90 \%$ of the chickens positive from line $\mathrm{F}$ and $\mathrm{S}$ respectively. It was unexpected that the chickens from line F had no body weight loss, because it was suggested that fast growing meat-type chickens are more susceptible to Salmonella compared with slow growing ones [13]. On the contrary, it has also been reported that meat-type chickens, which grow fast, are more resistant to Salmonella compared with laying-type lines [8]. So overall the relation between Salmonella susceptibility and growth rate is not unambiguous. Nevertheless the two chicken lines used in this experiment showed a clear difference in outcome of a Salmonella infection and it was interesting to further analyse their intestinal responses to the Salmonella infection and to compare gene expression between these lines and lines that were used in an earlier study [23].

At day $1 \mathrm{pi}$, the isolated intestinal mononuclear cells from the Salmonella infected chickens from line $\mathrm{F}$ had a higher phagocytic activity than the control animals. These differences were not due to differences in the amount of macrophages as determined by immunohistochemistry. Possibly the macrophages of the infected animals are more active. 
When the macrophages are more active, less Salmonella bacteria are able to survive. Indeed the number of cfu Salmonella in the liver of the infected animals from line F were significantly lower than in the infected chickens from line S. Another option is that the isolated cell suspension of the infected animals from line $\mathrm{F}$ are of a different composition compared with the cell suspension of the control animals. The percentage of macrophages in the isolated cell population can differ between infected and control animals causing the difference in the number of phagocytosed bacteria. The infected animals had a lower percentage of $\mathrm{CD} 45^{+}$cells (marker for leukocytes) in the isolated cell population, thus other non $\mathrm{CD} 45^{+}$cells were used in our phagocytose assay, because the amount of mononuclear cells used in the assay was equal among the groups. Thus, either the macrophages are more active or other cells are responsible for a better phagocytic activity in the cell population isolated from the Salmonella infected animals.

At day 5 pi, differences in the phagocytic activity between the intestinal mononuclear cells between the infected and the control chickens were found for line $\mathrm{S}$ instead of line $\mathrm{F}$ as for day 1 pi. This was also not caused by differences in the amount of macrophages. Here no differences in the amount of $\mathrm{CD} 45^{+}$cells in the isolated cell populations were found. At day 7 no differences in phagocytic activity of the intestinal mononuclear cells were found, which is in agreement with an earlier study [12]. Unfortunately in that study, no earlier timepoints than day 7 pi were investigated. So we found at early timepoints post infection differences in the phagocytic activity of the mononuclear cells from the intestine of control and Salmonella infected animals, but the causes of these differences are not known.

The number of $\mathrm{CD}^{+}{ }^{+}$was decreased in line F in response to the Salmonella infection, but not in line $\mathrm{S}$. This is surprising because in most studies an increase in the amount of $\mathrm{CD}^{+}$T-cells in the caeca was found after a Salmonella infection $[1,6]$. Also in mice the number of $\mathrm{CD}^{+}{ }^{+} \mathrm{T}$-cells increased in the gut following Salmonella challenge $[2,15]$. Furthermore in the ovary and oviduct of laying hens, increased numbers of $\mathrm{CD}^{+}{ }^{+} \mathrm{T}$-cells were reported after a Salmonella infection $[4,25,26]$. However, for the early host response $\mathrm{CD}^{+}{ }^{+}$or $\mathrm{CD}^{+}$ T-cells are probably not required [14]. In addition here young chickens were investigated where the intestinal immune system is immature, which could be a reason that no increase in $\mathrm{CD}^{+}{ }^{+} \mathrm{T}$-cells was found. For $\mathrm{CD}^{+}$cells, we found an increase after the Salmonella infection in both chicken lines, but faster in time post infection in line F. An increase in the amount of $\mathrm{CD}^{+}$ cells was also found in the caeca after a Salmonella infection $[1,6]$, but also decreases in the amount of CD8+ cells in the caeca are reported [18]. In the oviduct of laying hens, the numbers of $\mathrm{CD}^{+}$cells were increased after a Salmonella infection $[4,25,26]$. Our and other results suggest that differences in influx of T-cell subpopulations after a Salmonella infection are dependent on the location in the digestive tract, infection dose, time post infection, age at the time of infection and genetic background of the chickens.

The gene expression as measured with the microarray and validated with quantitative PCR in the jejunum at day 1 pi in these two chicken lines was partial in correspondence with our earlier study [23]. Besides differences in gene expression responses between the two chicken lines, we again saw upregulation in both lines of cytidine deaminase, similar to fatty acid synthase, dickkopf homolog 3 and similar to DNA segment, Chr 10, Johns Hopkins University 81 expressed in response to the Salmonella infection. It is noteworthy that all these genes were more upregulated in line $\mathrm{S}$, which had higher growth retardation and more cfu in the liver after the 
Salmonella infection than line F. However, in earlier experiments no relation was found with severity of the systemic infection and level of upregulation [23]. So these four genes are upregulated during a Salmonella infection, irrespective of the severity of the systemic infection and the growth retardation.

Some of the downregulated genes due to the Salmonella infection in line $\mathrm{S}$ might be related to decreased amounts of macrophages, as shown by in situ hybridization. One of the downregulated genes is carboxypeptidase $\mathrm{M}$, a macrophage differentiation marker [17]. Also similar to ORF2 (LOC428036) was downregulated, whereas this gene was shown before to be upregulated in avian macrophages after phagocytosis of Escherichia coli [7], so lower expression levels of this genes might indicate a decrease in the amount of macrophages.

This is the first report about changes in T-cell subpopulations and macrophages in the chicken jejunum in response to a Salmonella infection in one day old broilers and these changes were different between the two lines used. We also found gene expression differences between the two chicken lines, so the genetic background of the chicken is important for their responses to Salmonella infection.

\section{REFERENCES}

[1] Asheg A., Levkut M., Revajova V., Sevcikova Z., Kolodzieyski L., Pistl J., T lymphocyte subpopulations and B lymphocyte cells in caecum and spleen of chicks infected with Salmonella enteritidis, Acta Histochem. (2002) 104:435-439.

[2] Bao S., Beagley K.W., France M.P., Shen J., Husband A.J., Interferon-gamma plays a critical role in intestinal immunity against Salmonella typhimurium infection, Immunology (2000) 99:464-472.

[3] Barrow P.A., Huggins M.B., Lovell M.A., Simpson J.M., Observations on the pathogenesis of experimental Salmonella ty- phimurium infection in chickens, Res. Vet. Sci. (1987) 42:194-199.

[4] Barua A., Yoshimura Y., Ovarian cellmediated immune response to Salmonella enteritidis infection in laying hens (Gallus domesticus), Poult. Sci. (2004) 83:997-1002.

[5] Beal R.K., Powers C., Wigley P., Barrow P.A., Kaiser P., Smith A.L., A strong antigenspecific T-cell response is associated with age and genetically dependent resistance to avian enteric salmonellosis, Infect. Immun. (2005) 73:7509-7516.

[6] Berndt A., Methner U., Gamma/delta $\mathrm{T}$ cell response of chickens after oral administration of attenuated and nonattenuated Salmonella typhimurium strains, Vet. Immunol. Immunopathol. (2001) 78:143-161.

[7] Bliss T.W., Dohms J.E., Emara M.G., Keeler C.L. Jr., Gene expression profiling of avian macrophage activation, Vet. Immunol. Immunopathol. (2005) 105:289-299.

[8] Guillot J.F., Beaumont C., Bellatif F., Mouline C., Lantier F., Colin P., Protais J., Comparison of resistance of various poultry lines to infection by Salmonella enteritidis, Vet. Res. (1995) 26:81-86.

[9] Henderson S.C., Bounous D.I., Lee M.D., Early events in the pathogenesis of avian salmonellosis, Infect. Immun. (1999) 67:3580-3586.

[10] Hughes E.A., Galan J.E., Immune response to Salmonella: location, location, location? Immunity (2002) 16:325-328.

[11] Jeurissen S.H., Janse E.M., Koch G., de Boer G.F., The monoclonal antibody CVI-ChNL68.1 recognizes cells of the monocytemacrophage lineage in chickens, Dev. Comp. Immunol. (1988) 12:855-864.

[12] Kramer J., Visscher A.H., Wagenaar J.A., Boonstra Blom A.G., Jeurissen S.H., Characterization of the innate and adaptive immunity to Salmonella enteritidis PT1 infection in four broiler lines, Vet. Immunol. Immunopathol. (2001) 79:219-233.

[13] Kramer J., Visscher A.H., Wagenaar J.A., Cornelissen J.B., Jeurissen S.H., Comparison of natural resistance in seven genetic groups of meat-type chicken, $\mathrm{Br}$. Poult. Sci. (2003) 44:577-585.

[14] Mastroeni P., Chabalgoity J.A., Dunstan S.J., Maskell D.J., Dougan G., Salmonella: immune responses and vaccines, Vet. J. (2001) 161:132-164. 
[15] Mittrucker H.W., Kaufmann S.H., Immune response to infection with Salmonella typhimurium in mice, J. Leukoc. Biol. (2000) 67:457-463.

[16] Rabsch W., Tschape H., Baumler A.J., Nontyphoidal salmonellosis: emerging problems, Microbes Infect. (2001) 3:237-247.

[17] Rehli M., Krause S.W., Kreutz M., Andreesen R., Carboxypeptidase $M$ is identical to the MAX.1 antigen and its expression is associated with monocyte to macrophage differentiation, J. Biol. Chem. (1995) 270:15644-15649.

[18] Sasai K., Aita M., Lillehoj H.S., Miyamoto T., Fukata T., Baba E., Dynamics of lymphocyte subpopulation changes in the caecal tonsils of chickens infected with Salmonella enteritidis, Vet. Microbiol. (2000) 74:345-351.

[19] Suzuki S., Pathogenicity of Salmonella enteritidis in poultry, Int. J. Food Microbiol. (1994) 21:89-105.

[20] Tusher V.G., Tibshirani R., Chu G., Significance analysis of microarrays applied to the ionizing radiation response, Proc. Natl. Acad. Sci. USA (2001) 98:5116-5121.

[21] Van Hemert S., Ebbelaar B.H., Smits M.A., Rebel J.M.J., Generation of EST and microarray resources for functional genomic studies on chicken intestinal health, Anim. Biotechnol. (2003) 14:133-143.

[22] Van Hemert S., Hoekman A.J., Smits M.A., Rebel J.M.J., Differences in intestinal gene expression profiles in broiler lines varying in susceptibility to malabsorption syndrome, Poult. Sci. (2004) 83:1675-1682.
[23] Van Hemert S., Hoekman A.J., Smits M.A., Rebel J.M.J., Early host gene expression responses to a Salmonella infection in the intestine of chickens with different genetic background examined with cDNA and oligonucleotide microarrays, Comp. Biochem. Physiol. D (2006) 1:292-299.

[24] Van Immerseel F., De Buck J., De Smet I., Mast J., Haesebrouck F., Ducatelle R. Dynamics of immune cell infiltration in the caecal lamina propria of chickens after neonatal infection with a Salmonella enteritidis strain, Dev. Comp. Immunol. (2002) 26:355-364.

[25] Withanage G.S., Sasai K., Fukata T., Miyamoto T., Baba E., Lillehoj H.S., T lymphocytes, B lymphocytes, and macrophages in the ovaries and oviducts of laying hens experimentally infected with Salmonella enteritidis, Vet. Immunol. Immunopathol. (1998) 66:173-184.

[26] Withanage G.S., Sasai K., Fukata T., Miyamoto T., Lillehoj H.S., Baba E., Increased lymphocyte subpopulations and macrophages in the ovaries and oviducts of laying hens infected with Salmonella enterica serovar Enteritidis, Avian Pathol. (2003) 32:583-590.

[27] Withanage G.S., Wigley P., Kaiser P., Mastroeni P., Brooks H., Powers C., Beal R., Barrow P., Maskell D., McConnell I., Cytokine and chemokine responses associated with clearance of a primary Salmonella enterica serovar Typhimurium infection in the chicken and in protective immunity to rechallenge, Infect. Immun. (2005) 73:5173-5182. 